\title{
Body size response of abyssal polychaetes to different nutrient regimes
}

\author{
GORDON L. J. PATERSON ${ }^{1}$, ADRIAN G. GLOVER ${ }^{2}$ and CLAIRE TILLMAN ${ }^{2}$ \\ ${ }^{1}$ Department of Zoology, The Natural History Museum, London SW7 5BD, UK. E-mail: gljp@nhm.ac.uk \\ ${ }^{2}$ Department of Zoology, The Natural History Museum, London SW7 5BD, UK
}

\begin{abstract}
SUMMARY: Analyses of body size of abyssal polychaetes were made from sites experiencing different levels of nutrient flux in the Pacific and Atlantic Oceans. Measuring polychaetes was problematical due to high levels of fragmentation, and width of the first chaetiger was used as a surrogate for body size. Results indicated that polychaetes were significantly smaller in Atlantic areas experiencing seasonal or periodic input of phytodetritus. This observation held not just for comparison of sizes of the total assemblage but also when comparisons were made at the family and species level. Not all families showed a response. In the Atlantic, individuals belonging to the families Cirratulidae, Spionidae and Sabellidae indicated size differences, while in the Pacific spionids were significantly smaller from phytodetrital sites. At the species level, six species - all deposit feeders - were significantly smaller from phytodetrital sites, while two nominally predator/omnivore species showed an increase in size. Two hypotheses for the size frequency of the Atlantic populations from phytodetrital sites are suggested - the juvenile recruitment hypothesis where the smaller population body size is because of an influx of newly recruited juveniles; and the allometric plasticity hypothesis which postulates a physiological response from populations from non-phytodetrital areas delaying reproduction and putting more energy into growth, hence resulting in a larger body size. It is hypothesised that the larger size in non-phytodetrital sites may be a response to starvation.
\end{abstract}

Keywords: deep-sea, infauna, body size, Atlantic Ocean, Pacific Ocean, phytodetritus.

RESUMEN: REACCIÓN EN EL TAMAÑO DE POLIQUETOS DEL FONDO MARINO FRENTE A DIFERENTES REGÍMENES NUTRICIONALES. Se han realizado análisis sobre el tamaño de algunos poliquetos de zonas abisales marinas con diferentes niveles de flujo de nutrientes en los océanos Atlántico y Pacífico. Dada la tendencia a romperse, la medición de dichos poliquetos fué problemática. Por esta razon, la anchura del primer chaetígero se ha tomado como sustituto del tamaño total. Los resultados indican que los poliquetos eran notablemente más pequeños en zonas donde el flujo de nutrientes era estacional u ocasional. Ésta observación no solo se aplica a la totalidad de la población, sino también al nivel taxonómico familiar y por especies. No todas las familias mostraron dicha relación. En el océano Atlántico, individuos pertenecientes a las familias Cirratulidae, Spionidae y Sabellidae mostraron diferencias de tamaño, mientras que en el océano Pacífico las familias Paraonidae y Spionidae eran de menor tamaño en zonas con aportación nutritiva. Al nivel de especie, seis especies, todas ellas detritívoras, eran más pequeñas en zonas con flujo de nutrientes, y otras dos especies, ambas consideradas carnívoras/omnívoras, eran más grandes en dichas donas. Un análisis de frecuencia de los distintos tamaños de poliquetos en estas zonas demuestran que el alto numero de tamaños menores no ha sido causado por una afluencia de juveniles. Se especula que el mayor tamaño de poliquetos encontrados en zonas con flujo de nutrientes estacional se debe a una reacción de inanición.

Palabras clave: mar profundo, endofauna, tamaño, Océano Atlántico, Océano Pacífico, fitodetritus.

\section{INTRODUCTION}

Abyssal infaunal assemblages derive, ultimately, most of their nutrients from the photic zone (Carney, 1989). The discovery in recent years that the arrival of such nutrients was variable, both temporally and spatially, has prompted a number of studies on the impact this variability, particularly seasonality, has on standing crop and diversity (for example Rice et al., 1995; Sibuet, et al., 1989; Smith et al., 1996; 1998). Within the polychaetes, the dominant macrofaunal component of the infau- 
TABLE 1. - The main biogeochemical features of the study sites (from Glover et al. 2001, 2002).

\begin{tabular}{|c|c|c|c|c|c|c|}
\hline Atlantic & PAP & TAP & & & MAP & EOS \\
\hline Sampling programme & $\begin{array}{l}\text { Discovery Cruise } 11908 \\
\text { August-September } 1989 ; \\
\text { Challenger cruise } 52701 \\
\quad \text { May } 1991\end{array}$ & \multicolumn{2}{|c|}{$\begin{array}{c}\text { Discovery cruise } 11909 \\
\text { October } 1989\end{array}$} & \multicolumn{2}{|c|}{$\begin{array}{c}\text { Discovery cruise } 12174 \\
\text { August } 1991\end{array}$} & $\begin{array}{l}\text { Discovery Cruise } 12700 \\
\text { September-October } 2003\end{array}$ \\
\hline Nutrient regime & Seasonal phytoplankton bloom & Aseasonal nutri & ent input & Aseasona & nutrient input & Aseasonal nutrient input \\
\hline POC flux $\left(\mathrm{g} \mathrm{C} \mathrm{m}^{-2} \mathrm{Yr}^{-1}\right)$ & $0.8^{\mathrm{a}}$ & $\mathrm{n} / \mathrm{a}$ & & & $1-0.57^{\mathrm{b}}$ & $0.3^{c}$ \\
\hline Sedimentation rate $\left(\mathrm{cm} \mathrm{kyr}^{-1}\right)$ & $3 \mathrm{~d}$ & $\mathrm{n} / \mathrm{a}$ & & & $1-1 \mathrm{e}$ & $0.5 \mathrm{f}$ \\
\hline Polychaete abundance (ind. $\mathrm{m}^{-2}$ ) & 342 & 258 & & & 70 & 143 \\
\hline No. of Box cores & 5 & 10 & & & 5 & 8 \\
\hline Pacific & $0 \mathrm{~N}$ & $2 \mathrm{~N}$ & & $\mathrm{~N}$ & $9 \mathrm{~N}$ & HOT (23 N) \\
\hline Sampling programme & $\begin{array}{l}\text { RV Thompson } \\
\text { November } 1992\end{array}$ & $\begin{array}{l}\text { RV Thompson } \\
\text { November } 1992\end{array}$ & $\begin{array}{l}\text { RV Th } \\
\text { Novem }\end{array}$ & $\begin{array}{l}\text { lompson } \\
\text { ber } 1992\end{array}$ & $\begin{array}{l}\text { RV Thompson } \\
\text { November } 1992\end{array}$ & $\begin{array}{l}\text { RV Mona Wave } \\
\text { August } 1992 ; \\
\text { February } 1993\end{array}$ \\
\hline Nutrient regime & Phytodetrital input & nytodetrital input & Phytodet & trital input & Non phyto inpu & No phyto input \\
\hline POC flux $\left(\mathrm{g} \mathrm{C} \mathrm{m}^{-2} \mathrm{Yr}^{-1}\right)^{\mathrm{g}}$ & & 1.3 & & & 0.44 & 0.4 \\
\hline Polychaete abundance (ind. $\mathrm{m}^{-2}$ ) & 336 & 240 & & 20 & 52 & 36 \\
\hline No. of box cores & 3 & 3 & & 3 & 3 & 3 \\
\hline
\end{tabular}

a Heuser and Khriponoff (1993), ${ }^{\mathrm{b}}$ Lampitt (1992); ${ }^{\mathrm{c}}$ Heuser and Khriponoff (1993); ${ }^{\mathrm{d}}$ Santos et al. (1994); ${ }^{\mathrm{e}}$ Weaver and Rothwell (1987);

${ }^{\text {f }}$ Rabouille et al. (1993); ' Smith et al. (1997).

na, studies by Paterson et al. $(1994 ; 1998)$ and Glover et al. $(2001,2002)$ have shown that there is a complex relationship between levels of nutrient flux and abyssal polychaete biodiversity. In the central Pacific, polychaete abundance appears directly related to particulate carbon flux (POC), while in the Atlantic the situation is less clear. In neither ocean does there appear to be a link between POC and species diversity.

The seasonal arrival of detrital remains of phytoplankton at abyssal depths has been shown to have a dramatic effect on some of the components such as megafaunal grazers and foraminifera (Gooday, 1988; Gooday and Turley, 1990; Thurston et al., 1998). Populations were able to increase in numbers to exploit the phytodetritus. The availability of potentially more nutritious material may also impact on growth rates and, therefore, size of individuals within populations. It is therefore possible that individuals from areas experiencing higher levels of nutrient flux may be able to grow faster to reach reproductive age more quickly (Calow, 1977), but potentially they may reach larger overall sizes compared with those from areas with notably less nutrients available. Comparison with studies on other taxa and environments suggest this (e.g. insects (Chown and Gaston, 1999; Moczek, 2002), fish (Conover and Present, 1990), lizards (Adolph and Porter, 1996), mammals (Brown et al, 1993)).

In the present study we compare polychaete body sizes from a number of abyssal sites in the NE Atlantic and the central Pacific. In both oceans the samples come from areas where seasonal or periodic deposition of phytodetritus occurs and from those which are effectively aseasonal. We aim to test whether varying levels of nutrients (as measured by POC flux) have an effect on polychaete body size.

\section{MATERIAL AND METHODS}

\section{Study sites}

In the Atlantic, populations of polychaetes were studied from contrasting sites: one with a distinctive seasonal nutrient input - the Porcupine Abyssal Plain (PAP, c. $48^{\circ} \mathrm{N}: 16^{\circ} \mathrm{W} .4800 \mathrm{~m}$ ), and three aseasonal sites - Tagus Abyssal Plain (TAP c. $38^{\circ} \mathrm{N}: 11^{\circ} \mathrm{W} 5010$ $\mathrm{m}$ ), Madeira Abyssal Plain (MAP, c. $31^{\circ} \mathrm{N}$ : $21^{\circ} \mathrm{W}$ $4500 \mathrm{~m}$ ) and the Cap Verde Abyssal Plain (EOS, c. $20^{\circ} \mathrm{N}$ : $30^{\circ} \mathrm{W} .4800 \mathrm{~m}$ ). Details of the sampling programmes are given in Rice et al., (1994) - PAP, Sibuet, et al. (1993) and Thurston et al. (1998) EOS and MAP, and Gage et al. (1995) - TAP. A summary of the biogeochemical characteristics of the sites is given in Table 1.

In the Pacific, populations of polychaetes were studied from EqPac sites, part of the US Joint Global Ocean Flux Study sites in the central Pacific. Four stations were sampled: $0^{\circ}, 2^{\circ}, 5^{\circ}$ and $9^{\circ} \mathrm{N}$, $140^{\circ} \mathrm{W}$, at depths between 4300 and $4900 \mathrm{~m}$. A further site at The Hawaii Ocean Time Series (HOTS, $23^{\circ} \mathrm{N}$ : $158^{\circ} \mathrm{W}$ ) station within the oligotrophic zone 
of the Pacific was also studied. Details of the sampling programme and sites are given in Glover et al. (2002) and Smith et al. (1996, 1997). Upwelling in the equatorial Pacific creates new production leading to deposition of phytodetritus on the ocean floor. The stations at $0^{\circ}, 2^{\circ}$ and $5^{\circ} \mathrm{N}$ were all within this region of new production and experienced episodic impacts of phytodetrital material. Table 1 gives details of the biogeochemical characteristics of the stations. EqPac samples were collected in November 1992, while the HOTS samples were collected in August 1992 and February 1993.

All samples were collected using a U.S.N.E.L. spade box corer with a $0.25 \mathrm{~m}^{-2}$ sample area. Details of sample processing are given in Paterson et al. (1994) and Glover et al. (2001).

\section{Measurement of worms}

Determining size of worms was difficult because of fragmentation. A proxy for total length was developed. The relationship between total length and the width of the first chaetiger was tested (Fig. 1, $\mathrm{n}=\mathrm{x}, \mathrm{R} 2=0.699, \mathrm{p}<0.0001$ ). This relationship suggested that the width of the first chaetiger would serve as a reasonable proxy for length of worm and therefore size.

Polychaetes do not necessarily show a clear linear relationship between growth and body length. Often there is a deterministic outcome to size where there is a set number of chaetigers in adults and, once reached, growth proceeds both as an increase

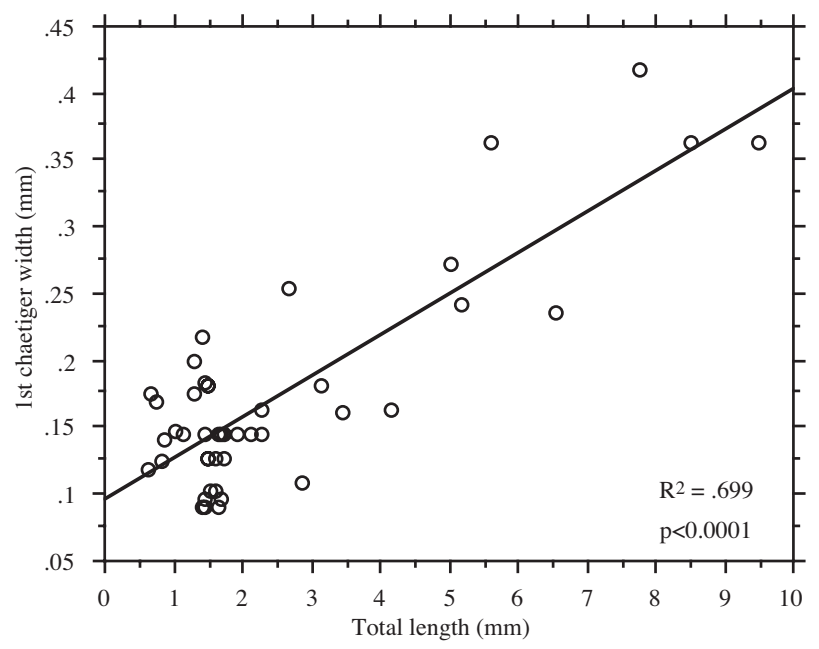

FIG. 1. - Relationship between total length of worm (all taxa) and width of $1^{\text {st }}$ chaetiger. While only a small number of the worms examined were complete, the graph indicates that the relationship is sufficient to be able to use the width of the $1^{\text {st }}$ chaetiger $(\mathrm{CH})$ as a surrogate for the size - length of the worm.
TABLE 2. - The numbers of individuals measured in the analyses of body size at each site and within the different categories and families.

\begin{tabular}{lcccc}
\hline \multirow{2}{*}{$\begin{array}{l}\text { Atlantic } \\
\text { Stations }\end{array}$} & Phytodetrital & \multicolumn{3}{c}{ Non phytodetrital } \\
& PAP & TAP & MAP & EOS \\
\hline Total & 357 & 58 & 63 & 164 \\
Cirratulidae & 101 & 30 & 5 & 54 \\
Sabellidae & 30 & 2 & 3 & 17 \\
Spionidae & 73 & 25 & 12 & 17 \\
\hline Pacific & Phytodetrital & \multicolumn{3}{c}{ Non phytodetrital } \\
\hline Total & 730 & \multicolumn{4}{c}{50} \\
Spionidae & 130 & \multicolumn{4}{c}{8} \\
\hline
\end{tabular}

in overall length and volume (see Emson et al., 1994 and Paterson and Glover, 2000 for examples). Nevertheless, given the constraints which we face with deep-sea species and the small size of most of the specimens collected by the box corer, we do not think that volumetric change will compromise our analyses significantly.

Measurements of the worms were made while examining the worms with a Olympus BH-2 interference contrast microscope. All worms were drawn and note made of the width of the first chaetiger and length of the first 10 chaetigers. In cases where the worm was intact a measurement of the complete worm was made.

\section{Statistical analyses}

Statistics were generated using StatView (SAS Institute). Comparisons of body size were made after $\log$ transformations of the first chaetiger width. All sizes conform to a log-normal distribution model. Multiple comparisons were made using ANOVA.

A three-stage approach was used in testing for size differences between the various sites. First, the whole polychaete assemblage was compared between stations, then families and finally between the same species occurring at different sites. A comparison was also made between stations experiencing phydodetrital input (PAP in the Atlantic, sites $0^{\circ}, 2^{\circ}, 5^{\circ} \mathrm{N}$ in the Pacific) and the non-phytodetrital sites (TAP, MAP and EOS in the Atlantic, sites $9^{\circ}$ and $23^{\circ} \mathrm{N}$ in the Pacific). Comparison at the species level is made between all phytodetrital and non-phytodtetrital sites to provide sufficient numbers of individuals for analysis. Table 2 gives the number of individuals analysed from each of the sites. 

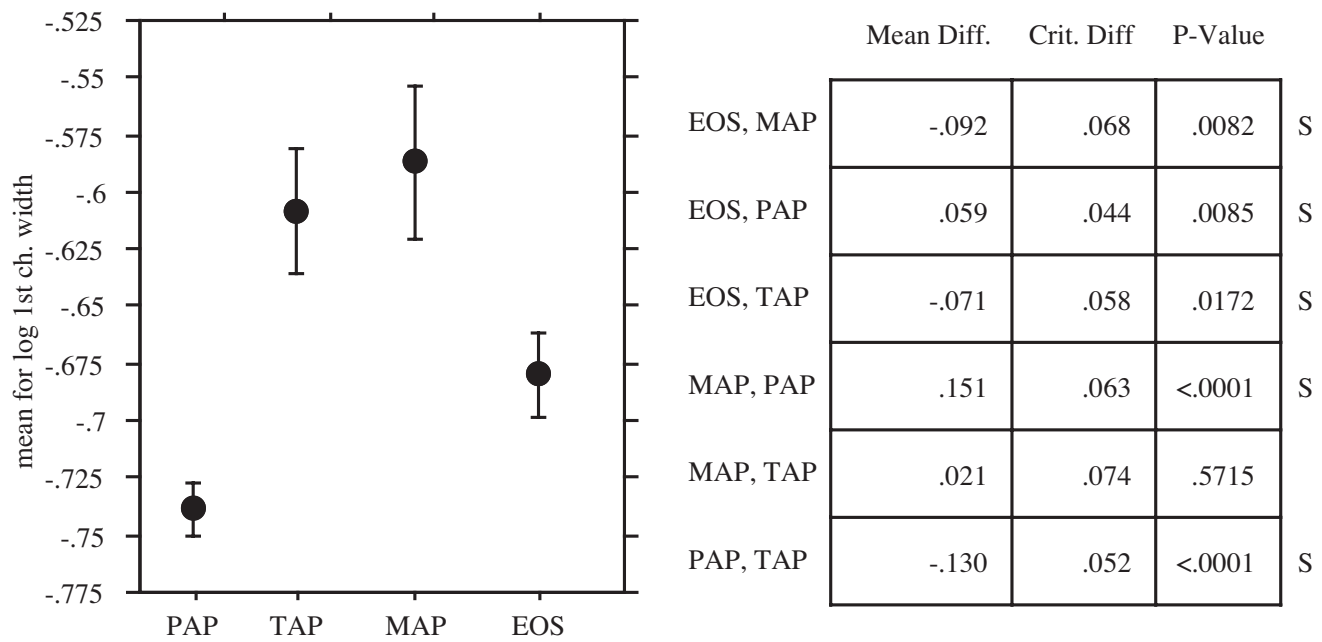

FIG. 2. - Comparison of polychaete assemblage size from Atlantic abyssal sites. Table give the results of the ANOVA analysis. S indicates $\neq \mathrm{a}$ significant difference between the sizes of the assemblage. Y-axis $=\log$ of width of $1^{\text {st }}$ chaetiger $(\mathrm{CH})$ in $\mathrm{mm}$.

\section{RESULTS}

Figure 2 indicates the size distribution of all polychaetes within each of the stations in the Atlantic abyss. PAP polychaetes were significantly smaller than the other sites $(\mathrm{p}<0.01)$. Also polychaetes at EOS were significantly smaller than at MAP and TAP $(\mathrm{p}<0.05)$ while larger than at PAP $(p<0.01)$. Polychaetes were $15 \%$ smaller at PAP compared to EOS and $28 \%$ smaller compared to polychaetes at TAP and PAP. In terms of phytodetrital against non-phytodetrital sites, polychaetes at PAP were significantly smaller than at sites not experiencing seasonal deposition of phytodetritus. Frequency histograms of the individual sites suggest that there is a similar distribution of size classes. Comparison of the histograms from PAP indicates that the distributions of individuals were significantly different to those at MAP (Kolmogorov-Smirnov $D=0.222, \mathrm{p}=0.0001)$, TAP $(D=0.237, \mathrm{p}=0.0003)$ but not significant different to those from EOS. The reason for the differences between the histograms may lie in distribution of larger individuals. In PAP and EOS there is a longer 'tail' of larger individuals, whereas in TAP and MAP larger individuals are absent (Fig. 3). Comparison of PAP with all the nonphytodetrital sites amalgamated indicated that individuals in populations experiencing phytodetrital input are significantly smaller than those from nonphytodetrital sites ( $p=0.0002$, Fig. 4 ) and that at PAP individuals of smaller body size represent a greater percentage of the assemblage (Fig. 3).

In the Pacific no obvious size differences were noted between the total polychaete assemblages at each of the sites with the exception of $0^{\circ} \mathrm{N}$ and $2^{\circ} \mathrm{N}$ (Fig. 5, p<0.0018). If comparison is made between individuals from all phytodetrital sites and those from non-phytodetrital sites, there is a similar trend, with phytodetrital sites having smaller polychaete body sizes (Fig. 4), but this is not statistically significant. It is probable that the main reason for this lack of significance is the low numbers of individuals recorded from the non-phytodetrital sites (Table 2). Two way ANOVA analysis of the Atlantic and Pacific and phytodetritus and non-phytodetritus indicates significant differences between the two oceans $(\mathrm{p}=0.0038)$ and between sites experiencing phytodetrital input and those where this input is absent $(\mathrm{p}=0.0002)$.

Differences in body size at the family level reveal that not all families show size variation and, therefore, different families may influence body size patterns within the total assemblage. In the Atlantic sabellids showed considerable variation in body size between different sites (Fig. 6). This variation mayhave strongly influenced the observed differences in assemblage body size noted among the sites. Also, cirratulid and spionid polychaetes were significantly smaller at PAP than at the other sites. Figure 7 shows a plot of size frequency within each family. The histograms indicate that the major difference between PAP and non-phytodetrital sites would appear to be caused by the presence of a number of larger individuals in the latter sites. Nevertheless, there is no obvious indication that the non-phytodetrital sites were characterised by a distribution of sizes skewed towards larger individuals.

In the Pacific, results of analyses of families between stations followed those of the total assem- 

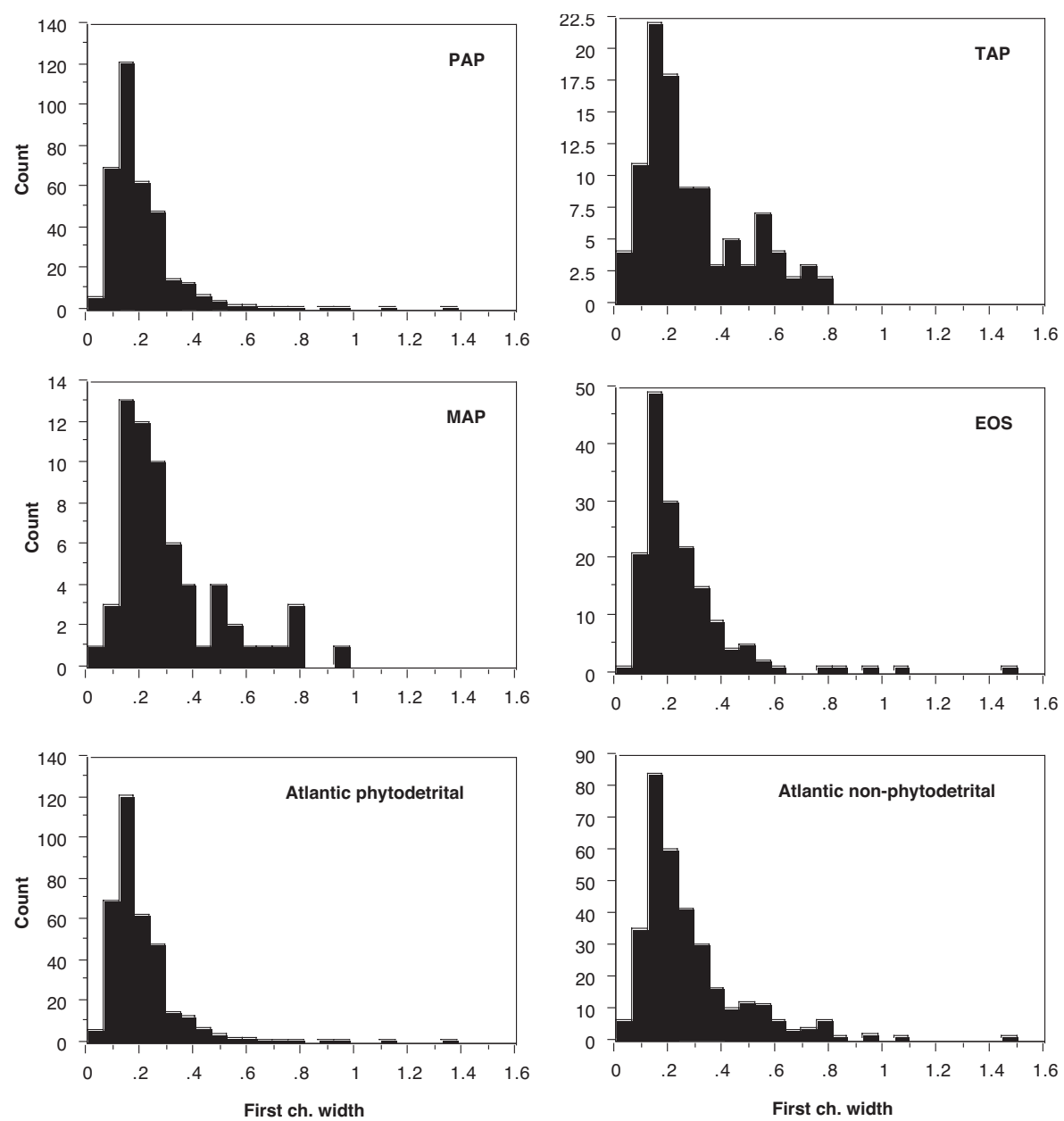

FIG. 3. - Histograms showing the size frequency of polychaetes from the different sites in the Atlantic. Note the differences in the vertical scale reflecting differences in abundance between the various study sites. Mean is given with standard error (SE) for each site. X-axis width of $1^{\text {st }}$ chaetiger in mm.

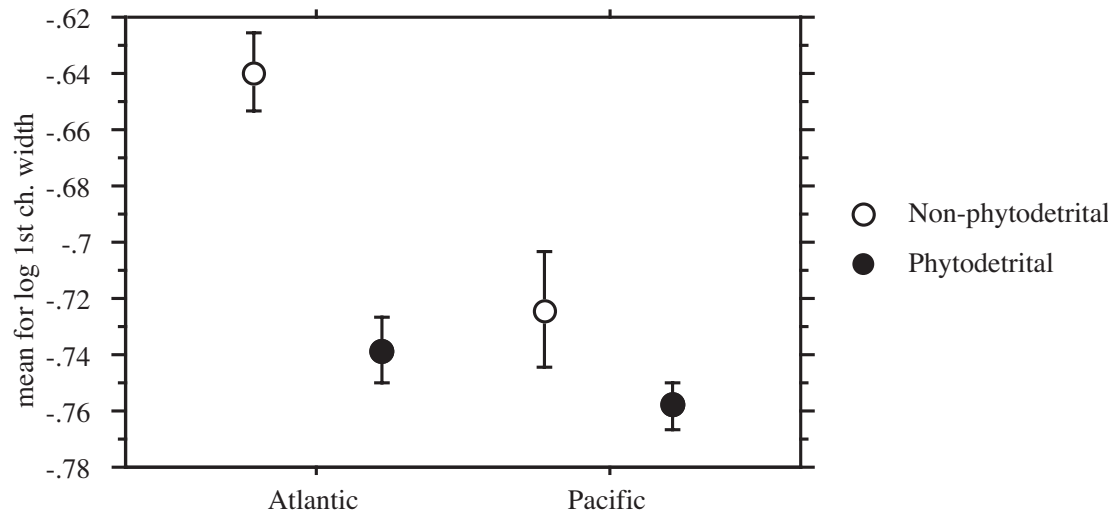

\begin{tabular}{l|r|r|r|r|r|r|r|}
\multicolumn{1}{c}{} & \multicolumn{1}{c}{ DF } & Sum of Squares & \multicolumn{2}{c}{ Mean Square } & \multicolumn{2}{c}{ F-Value } & \multicolumn{2}{c}{ P-Value } & \multicolumn{2}{c}{ Lambda } & \multicolumn{1}{c}{ Power } \\
\cline { 2 - 8 } Ocean & 1 & .390 & .390 & 8.388 & .0038 & 8.388 & .841 \\
\cline { 2 - 8 } Food Effect & 1 & .634 & .634 & 13.642 & .0002 & 13.642 & .974 \\
\cline { 2 - 8 } $\begin{array}{l}\text { Ocean * Food Effect } \\
\text { Residual }\end{array}$ & 1 & .149 & .149 & 3.207 & .0735 & 3.207 & .415 \\
\cline { 2 - 8 } & 1339 & 62.253 & .046 & & & & \\
\hline
\end{tabular}

FIG. 4. - Comparison of sites experiencing phytodetrital input with non-phytodetrital sites. In both the Atlantic and Pacific there are significant differences in the size of polychaetes with the assemblages from the phytodetrital sites being smaller. 


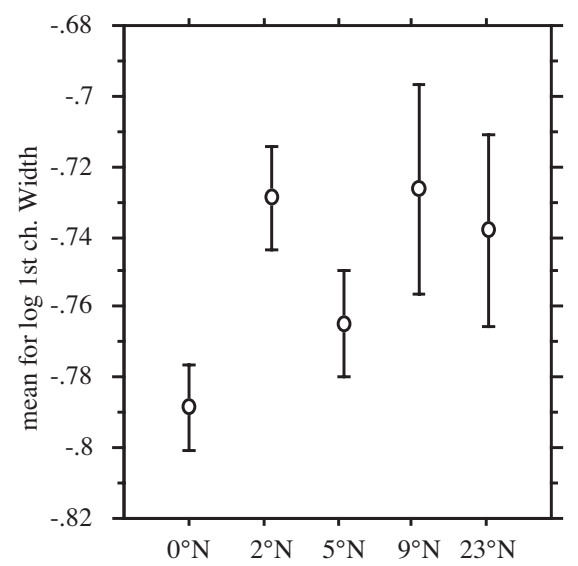

\begin{tabular}{l|c|c|c|}
\multicolumn{1}{c}{} & \multicolumn{1}{c}{ Mean Diff. } & \multicolumn{1}{c}{ Crit. Diff } & \multicolumn{1}{c}{ P-Value } \\
\cline { 2 - 4 } $0^{\circ} \mathrm{N}, 2^{\circ} \mathrm{N}$ & -.050 & .086 & .2514 \\
\cline { 2 - 4 } $0^{\circ} \mathrm{N}, 2^{\circ} \mathrm{N}$ & -.060 & .037 & .0018 \\
\cline { 2 - 4 } $0^{\circ} \mathrm{N}, 5^{\circ} \mathrm{N}$ & -.024 & .037 & .2024 \\
\cline { 2 - 4 } $0^{\circ} \mathrm{N}, 9^{\circ} \mathrm{N}$ & -.062 & .077 & .1152 \\
\cline { 2 - 4 } $23^{\circ} \mathrm{N}, 2^{\circ} \mathrm{N}$ & -.009 & .087 & .8357 \\
\cline { 2 - 4 } $23^{\circ} \mathrm{N}, 5^{\circ} \mathrm{N}$ & .026 & .087 & .5505 \\
\cline { 2 - 4 } $23^{\circ} \mathrm{N}, 9^{\circ} \mathrm{N}$ & -.012 & .110 & .8365 \\
\cline { 2 - 4 } $2^{\circ} \mathrm{N}, 5^{\circ} \mathrm{N}$ & .036 & .039 & .0719 \\
$2^{\circ} \mathrm{N}, 9^{\circ} \mathrm{N}$ & -.002 & .078 & .9521 \\
\cline { 2 - 4 } $5^{\circ} \mathrm{N}, 9^{\circ} \mathrm{N}$ & -.038 & .078 & .3384 \\
\cline { 2 - 4 } & & &
\end{tabular}

FIG. 5. - Comparison of polychaete size for the whole assemblage from each of the EqPac sites. The table gives the ANOVA analysis. Only $0^{\circ} \mathrm{N}$ and $2^{\circ}$ sites indicate significant differences in size.
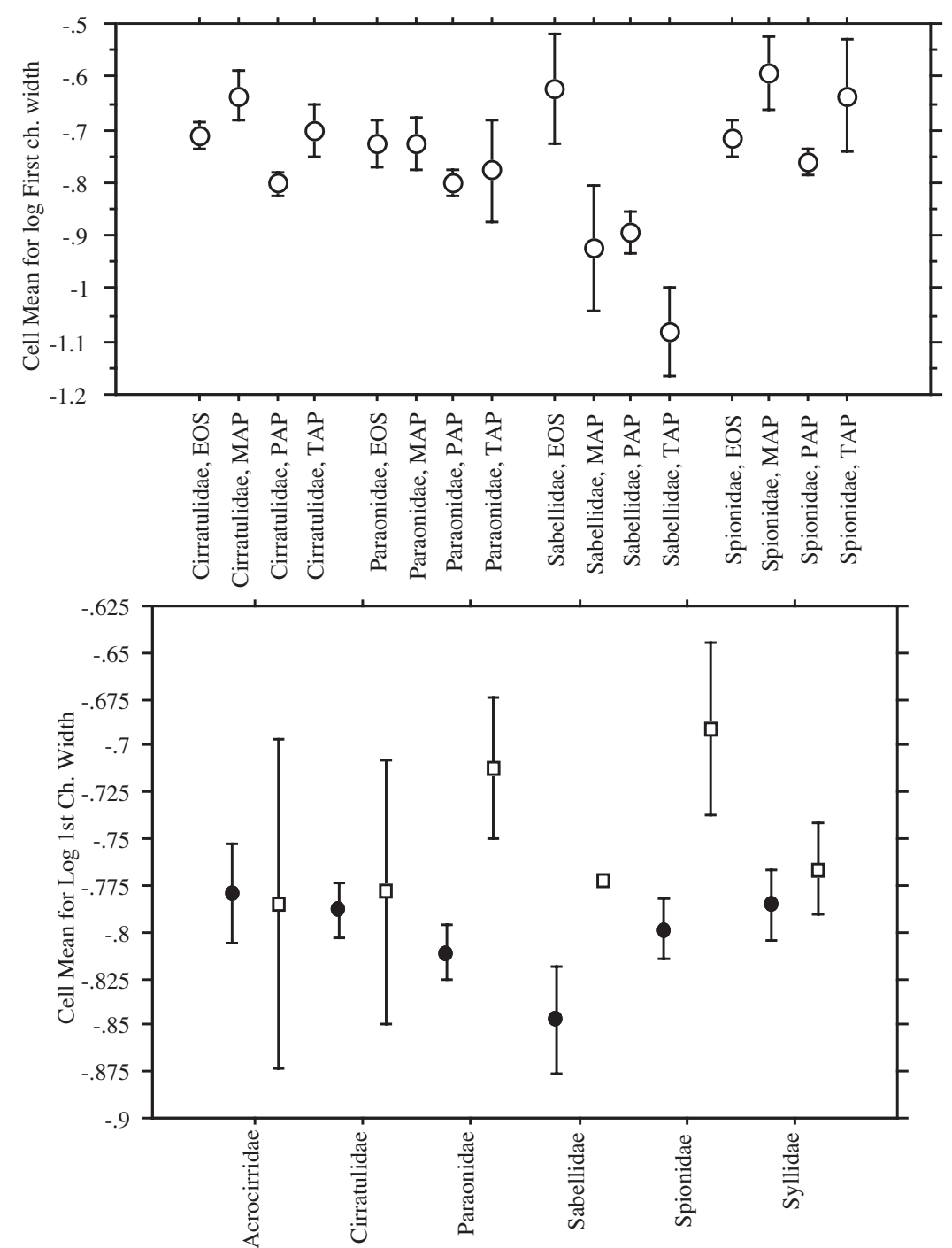

FIG. 6. - Variation in size of different families within the Atlantic (top) and Pacific (lower). Cirratulidae and Spionidae are significantly smaller at PAP than other sites; Sabellidae show considerable between site variation with specimens from PAP, MAP and TAP significantly smaller than EOS; Paraonidae specimens show no significant differences in size between the sites. E - EOS, M - MAP, P - PAP, T - TAP. The lower figure shows the same analyses for the dominant species in the EqPac studies. Samples have been amalgamated into sites with phytodetrital input (filled circles) and non-phytodetrital sites (open circles). Although the Paraonidae appear to show that individuals at the phytodetrital sites are smaller this is not significant $(\mathrm{p}=0.0503)$. Only the individuals of Spionidae are significantly smaller in phytodetrital sites $(\mathrm{p}=0.02)$. 

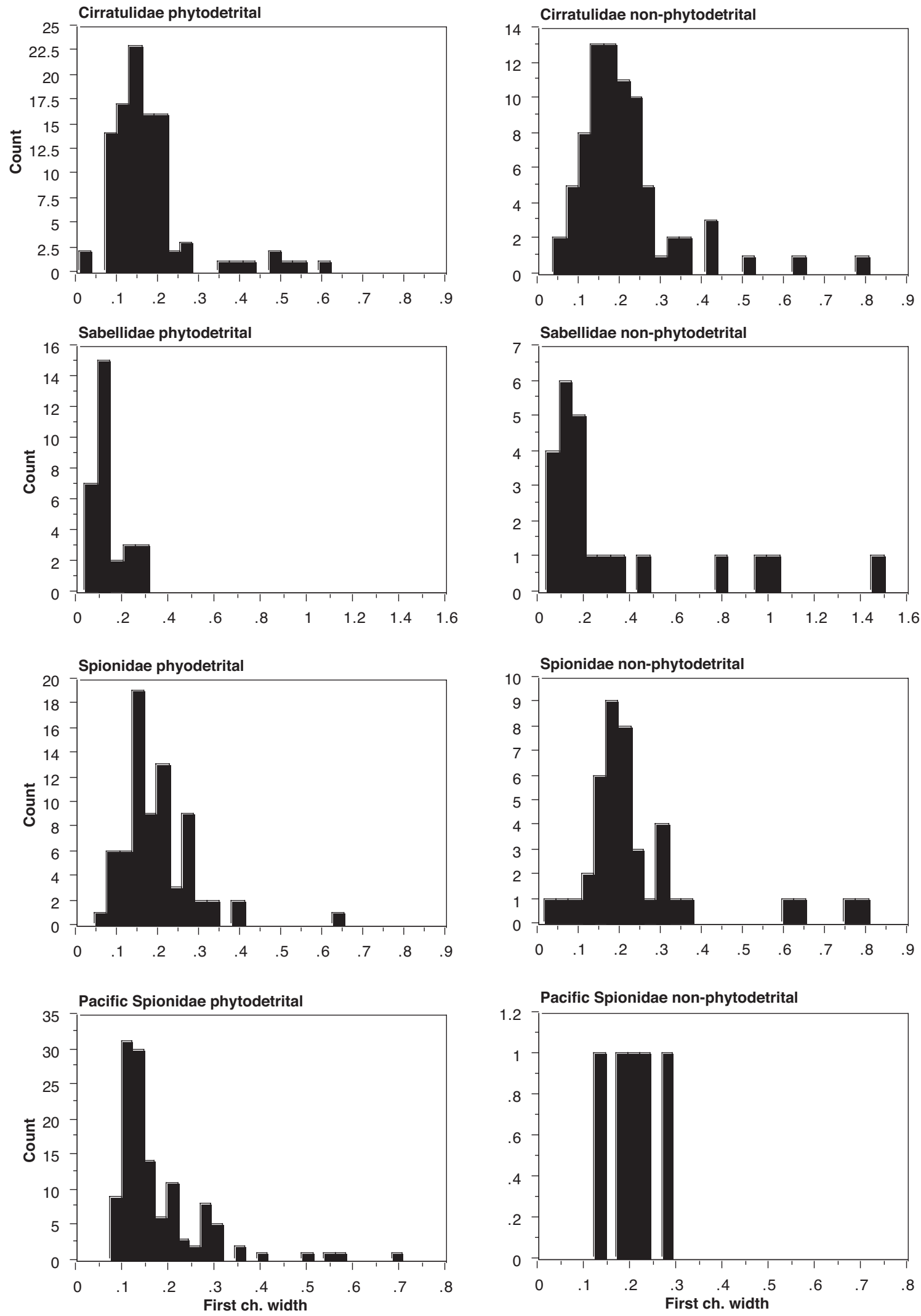

FIG. 7. - Histograms of size frequency for families showing significant differences between phytodetrital and non-phytodetrital sites in the Pacific and Atlantic. X-axis gives the width of the $1^{\text {st }}$ chaetiger in $\mathrm{mm}$. 

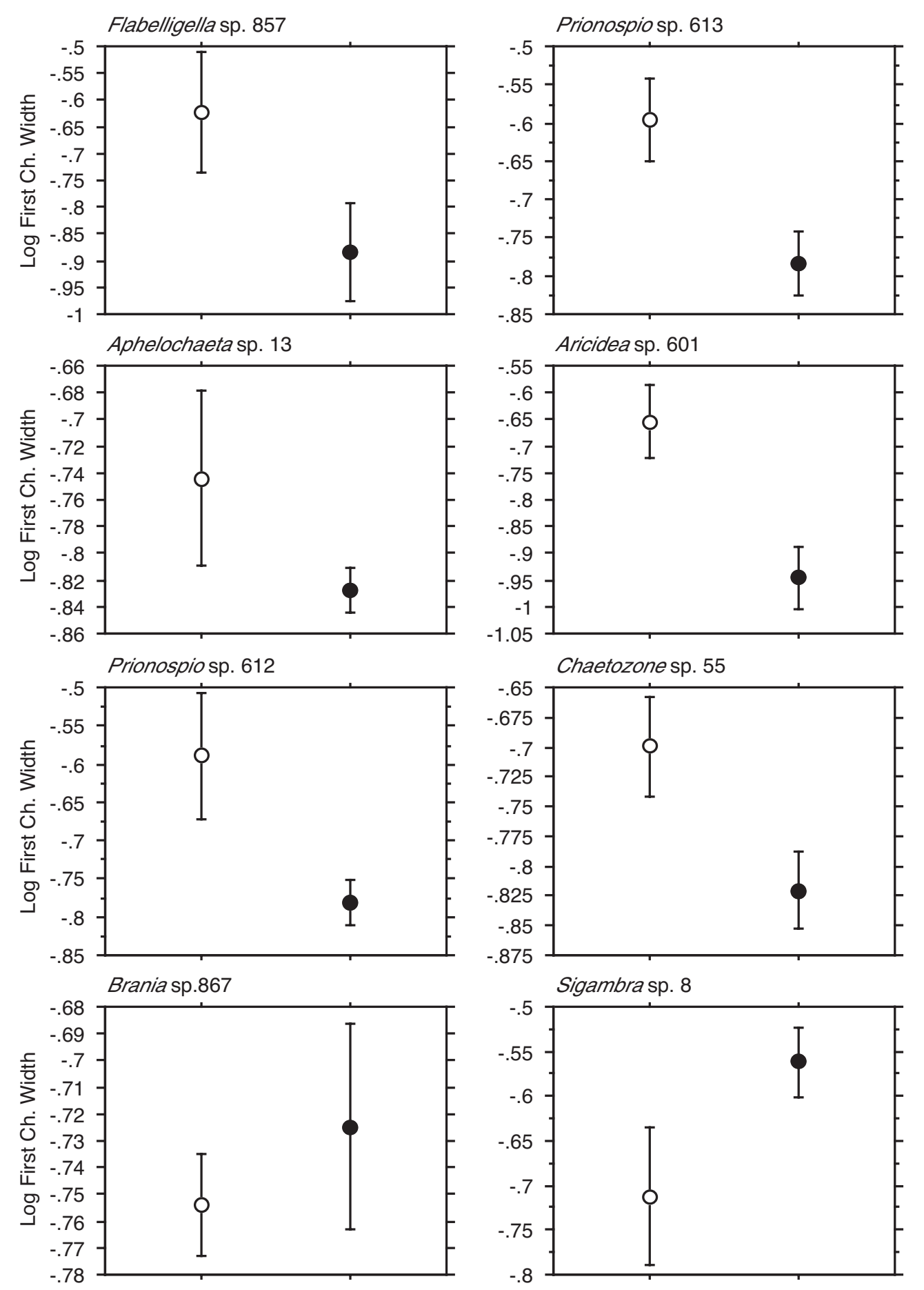

FIG. 8. - Comparison of body size of species which occur at both phytodetrital sites (open circles) and non-phytodetrital sites (black circles). Graphs are for species which show significant differences in size. With the exception of Brania sp 867 and Flabelligera sp 857 which were collected from the Pacific, the remaining species were collected from the NE Atlantic sites. It was necessary to amalgamate data from a number of sites into phytodetrital and non-phytodetrital areas to gain enough individuals to perform the comparison. Sigambra sp8 = Sigambra magnuncus.

blage, with no obvious pattern. However, if phytodetrital sites are compared with non-phytodetrital sites then a significant difference is noted for spionids; the body size of individuals of this family being $30 \%$ smaller at phytodetrital sites (Figs. 6, 7).
Finally, comparison of species common to different stations was limited by high species endemism between stations and low sample abundance (Paterson et al, 1998 and Glover et al. 2001 give abundance and diversity details of these stations). 
Nevertheless, some comparisons can be made. Six species from the Atlantic and two from the Pacific occurred in sufficient numbers to allow a comparison to be made (Fig. 8). The results show that the body size of individuals was significantly smaller from phytodetrital sites than from non-phytodetrital sites, with two exceptions Brania sp867 and Sigambra magnuncus Paterson and Glover, 2000. In both these cases individuals from phytodetrital sites are significantly larger. Species which showed a decrease in size could be termed detritivores while the two species showing an increase in size at phytodetrital sites could be termed predators or omnivores.

\section{DISCUSSION}

The results above show that there were significant differences in body size between polychaetes from phytodetrital and non-phytodetrital sites in the Atlantic. Further analyses indicate, however, that the response may be most marked in particular groups or families and is not necessarily a general phenomenon throughout the assemblage. There were also differences between oceans in the families which showed a response, with only spionids showing the same response in both the Atlantic and Pacific. Care must be taken in over-interpreting this, however, as the numbers of individuals involved were low, particularly in the oligotrophic Pacific sites (Table 2; see also Glover et al., 2002).

Increased availability of nutrients should result in larger individuals. Data from the abyssal assemblage studies reported here have demonstrated that more nutrients are available at stations where there is a noted phytodetrital input (Table 1). So our findings that polychaetes from phytodetrital sites were significantly smaller than those from non-phytodetrital areas may, at first, appear counter-intuitive. There are two main hypotheses which could account for this observation. The first is that the phytodetrital input acts as a timing mechanism and the reproductive cycle of polychaetes in the abyss is triggered by such an event. The production of juveniles at a time when there is increased availability of nutrients would result in a smaller average body size for the polychaete assemblage. The results reported are, therefore, a reflection of increased numbers of juveniles, or at least smaller growth stages in the assemblage, and that sampling at a different time of year would find larger individuals and no difference between sites. This might be termed juvenile recruitment hypothesis.

The second hypothesis is that there is a change in the physiological trajectory such that species take advantage of the increased nutrients to switch from growth to reproduction at an earlier stage. In areas where there is no periodic input of nutrients, sequestration of nutrients is slower and polychaetes put more resources into growth. Therefore, time to reach reproductive size is longer with individuals reaching a larger body size. This might be termed the allometric plasticity hypothesis. What evidence is there to test these explanations?

\section{Juvenile recruitment hypothesis}

In the Atlantic, sampling is potentially compromised by temporal pseudoreplication (Hulbert, 1984). Sampling was carried out at different times of year and in different years. Nevertheless, by assuming that there is periodicity in reproduction and/or that reproduction is more continuous year round - a common pattern in deep-sea species (Gage and Tyler, 1991) - it is possible to make comparisons between sites. In the Atlantic most cruises took place in late spring and through the summer (May to October). At PAP sampling took place around the time of (Discovery 52701), or after (Discovery 11908) the phytodetrital event (Billet et al., 1992; Rice et al., 1994; Thurston et al., 1998). Potentially, the assemblage at PAP may have included growing individuals, particularly of opportunistic species. If juvenile or small forms dominated the sample, as suggested by the hypothesis, we would expect to see a greater proportion of the assemblage comprised of smaller body sizes.

Comparison of polychaete sizes between cruises 11908 and 52701 does indicate that polychaetes from the later sample are larger, which supports this hypothesis. However, Figure 2 shows histograms of polychaete size distribution for the Atlantic sites; PAP samples were taken in May (Fig. 2) and show a similar distribution of body size to EOS samples taken in September. The significant differences in size distribution noted between MAP and TAP with PAP (and EOS) appear to be a result of the presence of larger individuals in the latter sites, not what would be predicted by the juvenile hypothesis. If non-phytodetrital site data are amalgamated and compared with PAP, such differences become less pronounced. These results do not point to differ- 
ences in size at the assemblage level being a result of an influx of juveniles. Care must be taken in this interpretation as the numbers of individuals involved are small and, given the intersample heterogeneity noted by Paterson et al. (1998), it is possible that sampling did not capture any large individuals at MAP and TAP.

Analyses of size distribution within families which showed differences between sites (Fig. 7), followed the same pattern as the total assemblage. There was a similar distribution of smaller sizes; in some cases, such as the sabellids, there were actually more small-sized individuals in the non-phytodetrital sites compared with PAP, with the main difference being the presence of larger individuals. Again, this pattern is not that robust given the low numbers of individuals involved.

In the Pacific the EqPac samples were taken within the same season and month so are directly comparable. Here, no significant difference was found between phyto and non-phytodetrital populations although a similar trend of smaller individuals at sites of phytodetrital input was noted. In the Spionidae the higher numbers of smaller-sized individuals supports the idea that there are more juveniles. However, analyses of families are hampered by their low abundance in non-phytodetrital sites, such that observed differences may be artefactual.

Thus, there is some evidence from the Atlantic and the Pacific that there may be some differences between populations taken at different times of year, pointing to a seasonal recruitment effect. However, it is also possible that this difference may be due to the presence of a greater number of larger individuals (i.e. sampling bias), and not to a change in the demographic structure of the polychaete assemblages.

\section{Allometric plasticity hypothesis}

Increased size is considered to provide a number of metabolic efficiencies (i.e. respiration). Larger females can also produce more eggs. Increases in body size have been linked with increased ability to withstand starvation (Spight, 1976; Cushman et al., 1993). Rex et al. (1998) and Clain and Rex (1999) found that in gastropods populations were larger from deeper parts of the species' bathymetric range. Deeper populations were also from areas experiencing less nutrient availability. These authors point to metabolic and competitive advantages in larger-sized individuals. In polychaetes there is evidence that longer gut length associated with larger body sizes can lead to more efficient utilisation of poorer quality of food. (Ahrens et al., 2001). While juvenile and small individuals are able to select food items with more nutrient quality, adults become less discriminating and consume items in bulk in order to provide enough energy (Penry and Jumars, 1990). Longer gut residence times are thought to result in greater absorption efficiency (Kofoed et al., 1989). If the same conditions apply to deep-sea polychaetes, it may be that the increased nutritional quality of input associated with phytodetrital material (Santos et al., 1994) makes it possible for polychaetes to remain at a smaller size at PAP. Whereas in the non-phytodetrital sites polychaetes put what energy is available into growth to maximise efficiency in gaining nutrition from the sediment and are potentially better able to withstand starvation while awaiting sufficient nutrients to switch to reproduction. This may also be consistent with the observation that among the individual species, only the putative carnivorous - omnivorous species showed an increase in size at phytodetrital sites. Presumably, these species were able to select prey/ high energy items.

The major difficulty with this hypothesis is that the difference in size between the assemblages is not that large. In general most polychaetes from the deep sea are small. The evidence with which to test between potential hypotheses is weak basically because of the low numbers and limited sampling. Nevertheless, the evidence available does point to a physiological response rather than a reflection of reproductive settlement.

Rex and Etter (1998) warn that in making such comparisons, particularly of total assemblages there is the danger of confusing clear signals whereby different families/species may be responding in different ways. We have tried to avoid this by looking at the responses at different taxonomic levels and have found that similar patterns emerge. That differences exist between the phytodetrital and non-phytodetrital sites has been shown, but the explanation is as yet not that clear. In particular our understanding of polychaete reproductive patterns and potential recruitment periods restricts interpretation of differences between populations. Further analysis of a seasonal time series from PAP may provide more information.

A final question may be asked, namely are all individuals of the fauna sampled by box corers during these studies actually juveniles? Rex et al. 
(2005) have put forward the hypothesis that in the abyss most populations are in fact non-reproducing - the result of immigration of larvae from reproductive populations on the slope. While we have no hard data to test this hypothesis for polychaetes we put forward the following observations which suggest that polychaetes may possess reproductive populations in the abyss. Firstly the small size is not a reflection of a juvenile fauna. There is no doubt that large polychaetes have been collected (e.g. results of the Challenger Expedition (MacIntosh 1885); Albatross Expedition (Chamberlain, 1919) Ingolf (Wesenberg-Lund 1950.). Glover (2000) and Hilbig (in press) have shown that with a number of small exceptions there is little overlap between the families collected by a dredge and those collected by quantitative gears such as the spade box corer. In addition, some specimens of cirratulids and ampharetids collected from the EqPac transect and from PAP have been shown to contain eggs. So the smaller element of the polychaetes appear to be adults and exploit the environment in a different way to the larger forms.

\section{ACKNOWLEDGEMENTS}

The authors would like to thank the masters, crews and scientific parties of the various oceanographic cruises, Discovery 11908, 11909, 12174 and 12600, Challenger 52701, Thomas Thompson (EqPac Leg) and Moana Wave (HOT). We thank Drs John D. Gage, David S. M. Billett, Brian J. Bett, Prof Paul A. Tyler for making the Atlantic abyssal samples available to us, Prof Craig R. Smith for his help and making the EqPac samples available for study. Thanks are also due to the various sorting teams of both Atlantic and Pacific samples. The Atlantic samples were collected during a MAST I and II programme and funding from this programme (MAS2-CT920033) supported GLJP's contribution. CT received an Undergraduate Research Bursary from the Nuffield Foundation which is gratefully acknowledged. We would like to thank Chris Barrio Frojan for comments on the manuscript.

\section{REFERENCES}

Adolph, S.C. and W.P. Porter. - 1993. Growth, seasonality and lizard life histories: age and size at maturity. Oikos, 77: 267-278.

Ahrens, M.J., J. Hertz, E.M. Lamoureux, G.R. Lopez, A.E.
McElroy, and B.J. Brownawell. - 2001. The effect of body size on digestive chemistry and absorption efficiencies of food and sediment-bound organic contaminants in Nereis succinea (Polychaeta). J. Exp. Mar. Biol. Ecol., 263: 185-209.

Billett, D.S.M., R.S. Lampitt, A.L. Rice and R.F.C. Mantoura. 1983. Seasonal sedimentation of phytoplankton to the deep-sea benthos. Nature, 302: 520-522.

Brown, J.H., P.A. Marquet and M.L. Taper. - 1993. Evolution of body size: consequences of an energetic definition of fitness. Am. Nat., 142: 573-584.

Calow, P. - 1977. Ecology, evolution and energetic: a study in metabolic adaptation. Adv. Ecol. Res., 10: 1-62.

Carney, R.S. - 1989. Examining relationships between organic flux and deep-sea deposit feeding. In: G.R. Lopez, G.R. Taghon and J. Levington (eds.), Ecology of Marine Deposit Feeders. pp, 2458. Springer Verlag, New York.

Chamberlain, R.V. - 1919. The Annelida Polychaeta. Mem. Mus. Comp. Zool., 48: 1-514.

Chown, S.L. and K.J. Gaston. - 1999. Exploring links between physiology and ecology at macro-scales: the role of respiratory metabolism in insects. Biol. Rev., 74: 87-120.

Clain, A.J. and M.A. Rex. - 2000. Size-depth patterns in two bathyal turrid gastropods: Benthomangelia antonia (Dall) and Oenopota ovalis (Friele). Nautilus, 114: 93-98.

Cushman, J.H., J.H. Lawton and J.T. Manly. - 1993. Latitudinal patterns in European ant assemblages: variation in species richness and body size. Oecologia, 95: 30-37.

Emson, R.H., C.R. Young and G.L.J. Paterson. - 1994. A fire worm with a sheltered life; studies of Benthoscolex cubanus (Polychaeta-Amphinomidae): an internal parasite of the bathyal sea urchin Archeopneustes hystrix. J. Nat. Hist., 27: 1013-1028.

Gage, J.D. and P.A. Tyler. - 1991. Deep-sea Biology: A Natural History of Organisms at the Deep-sea Floor. Cambridge University Press, Cambridge.

Gage, J.D., P.A. Lamont and P.A. Tyler. - 1995. Deep-sea macrobenthic communities at contrasting sites off Portugal, preliminary results: I. introduction and diversity comparisons. Int. rev. Ges. Hydrobiol., 80: 235-250.

Glover, A.G. - 2000. Abyssal polychaete assemblages along latitudinal gradients of productivity in the equatorial Pacific and North Atlantic Oceans. Ph.D. thesis Univ. Southampton.

Glover, A.G., G.L.J. Paterson, B.J. Bett, J.D. Gage, M. Sibuet, M. Sheader, L.E. Hawkins. - 2001. Patterns in polychaete abundance and diversity from the Madeira Abyssal Plain, northeast Atlantic. Deep-Sea Res. I, 48: 217-236.

Glover, A.G., C.R. Smith, G.L.J. Paterson, G.D.F. Wilson, L.E. Hawkins, and M. Sheader. - 2002. Polychaete species diversity in the central Pacific abyss: local and regional patterns, and relationships with productivity. Mar. Ecol. Prog. Ser., 240: 157-170.

Gooday A.J. - 1988. A response by benthic Foraminifera to the deposition of phytodetritus in the deep sea. Nature, 332: 70-73.

Gooday, A.J. and C.M. Turley. - 1990. Responses by benthic organisms to inputs of organic material to the sea floor: a review. Phil. Trans. Roy. Soc. Lond. A, 331: 119-138.

Hilbig, B. - 2004 Polychaetes of the deep Weddell and Scotia Seas. Deep-Sea Res. II, 51: 1817-1825.

Hueser and A. Khripounoff. - 1993. Variation des flux de carbone dans l'Atlantique nord. Courier de JGOFS France, 1: 14-15

Hulbert, S.H. - 1984. Psuedoreplication and the design of ecological field experiments. Ecol. Monog., 54: 187-211.

Kofoed, L.H., V.E. Forbes and G.R. Lopez. - 1989. Time dependent absorption in deposit feeders. In: G.R. Lopez, G.R. Taghon, and J. Levington (eds.), Ecology of Marine Deposit Feeders. pp, 129-148. Springer Verlag, New York.

McIntosh, W.C. - 1885. Report on the Annelida Polychaeta collected by H.M.S. Challenger during the years 1873-1876. Rep. Sci.res. voy. HMS Challenger, 12: 1-544.

Moczek, A.P. - 2002 Allometric plasticity in a polyphenic beetle. Ecol. Entomol., 27: 58-67.

Paterson, G.L.J., J.D., Gage, P.A. Lamont, B.J. Bett and M.H. Thurston. - 1994. Patterns of abundance and diversity from the abyss - polychaetes from NE Atlantic abyssal plains. Mém. Mus. Hist. Nat., 162: 503-509.

Paterson, G.L.J., G.D.F. Wilson, N. Casson and P.A. Lamont. 1998. Hessler and Jumars (1974). revisited: abyssal polychaete assemblages from the Atlantic and Pacific. Deep-Sea Res. II, 
45: 225-251.

Paterson, G.L.J. and A.G. Glover. - 2000. A new species of Sigambra (Polychaeta: Pilargidae) from the abyssal N E Atlantic. Bull. Nat. Hist. Mus. Zool., 66: 167-170.

Penry, D.L. and P.A. Jumars. - 1990. Gut architecture, digestive constraints and feeding ecology of deposit feeding and carnivorous polychaetes. Oecologia, 82: 1-11.

Rabouille, C., J.-F. Gaillard, M. Sibuet, C. Beaucaire, P. Bonté, P. Crassous, R. Janke, A. Khripounoff, F. Legeleux, J. Laureillard, J. Méjanelle, C. Pierre, J.-C Reflexans and J.-L. Reyss. - 1993. Sediment geochemistry in the three EUMELI sites in the tropical NE Atlantic: general presentation and first results. Annal. Inst. Océanogr., 69: 35-42.

Rex, M.A. and R. J. Etter. - 1998. Bathymetric patterns of body size: implications for deep-sea biodiversity. Deep-Sea Res. II, 45: 103-127.

Rex, M.A., R.J. Etter, A.J. Clain and M.S. Hill. - 1999. Bathymetric patterns of body size in deep-sea gastropods. Evol., 53: 12981301.

Rex, M.A, C.R. McClain, N.A. Johnson, R.J. Etter, J.A. Allen, P. Bouchet, A. Waren. - 2005. A source-sink hypothesis for abyssal biodiversity. Am. Nat., 165: 163-178.

Rice, A.L., M.H. Thurston, and B.J. Bett. - 1994. The IOSDL DEEPSEAS programme: introduction and photographic evidence for the presence and absence of seasonal input of phytodetritus at contrasting abyssal sites in the northeastern Atlantic. Deep-Sea Res. I, 49: 1305-1320.

Rice, A.L. et al. - 1995. Community structure and processes in the Deep-sea benthos. Final Report MAST contract MAS2CT920033. 300 pp.

Santos, V., D.S.M. Billett, A.L. Rice and G.A. Wolff. - 1994. Organic matter in deep-sea sediments from the porcupine abyssal plain in the NE Atlantic Ocean. I- Lipids. Deep-Sea Res. I, 41: 787-819.
Sibuet, M., C.E., Lambert, R. Chesslet and L. Laubier. - 1989. Density of the major size groups of benthic fauna and trophic input in the deep basins of the Atlantic Ocean. J. Mar. Res., 47: 851-867.

Sibuet, M., P. Albert, Charmassons, J. Deming, A. Dinet, J. Galeron, L. Guidi-Guilvard, and M.L. Mahaut. - 1993. The benthic ecosystem in the three EUMELI sites in the northeast tropical Atlantic: general perspectives and initial results on biological abundance and activities. Annal. Inst. Océanogr., 69: 21-33.

Smith, C.R., D.J. Hoover, S.E. Doan, R.H. Pope, D.J. DeMasters, F.C. Dodds, and M.A. Altabet. - 1996. Phytodetritus at the abyssal seafloor across $10^{\circ}$ latitude in the central equatorial Pacific. Deep-Sea Res. II, 43: 1309-1339.

Smith, C.R., W, Berelson, D.J. DeMasters, F.C. Dodds, D Hammond, D.J. Hoover, R.H. Pope, and M. Stevens. - 1997. Latitudonal variations in the benthic processes in the abyssal equatorial Pacifci: control by biogenic particle flux. Deep-Sea Res. II, 44: 2295-2317.

Spight, T.M. - 1976. Ecology of hatching size in marine snails. Oecologia, 24: 283-294.

Thurston, M.H., A.L. Rice and B.J. Bett. - 1998. Latitudinal variation in invertebrate abyssal megafauna in the North Atlantic Ocean. Deep-Sea Res. I, 45: 203-224.

Weaver, P.P.E. and R.G. Rothwell. - 1987. Sedimentation of the Madeira Abyssal Plain over the past 300 years. In: P.P.E. Weather and J. Thompson (eds.), Geology and Geochemistry of Abyssal Plains. pp. 71-86. Blackwell Scientific Publications, Oxford.

Wesenberg-Lund, E. - 1950. Polychaeta. Danish Ingolf Exped., 4: $1-92$.

Received September 10, 2004. Accepted May 11, 2005. 